\title{
PERFORMANCE EVALUATION OF BRAZILIAN MUNICIPALITIES FROM THE IMPLEMENTATION OF THE TAX MANAGEMENT MODERNIZATION PROGRAM - PMAT
}

DUTRA, Ademar*

\author{
PLATT, Ana Paula Adriano \\ ENSSLIN, Sandra Rolim \\ RIPOLL-FELIU, Vicente Mateo \\ CASAGRANDE, Jacir Leonir
}

\begin{abstract}
The Federal Government has made available to Brazilian municipalities the PMAT in order to modernize and strengthen tax administration. Because it is public money, it becomes necessary to implement measures to control the application of the Program investments. The objective of this research is to propose a model of performance evaluation for municipalities that implemented PMAT, which aims to: (i) identify the objectives, characteristics and criteria required by PMAT to enable municipal governments in obtaining resources, (ii) define the criteria needed to make the model structure for evaluating the performance of municipalities from the implementation of PMAT (iii) determine the parameters of judgment to allow evaluation of the municipalities. To achieve the objectives of the research it was conducted an exploratory study with qualitative / quantitative approaches. Data were collected using semi-structured interviews. As a result of research we propose a model of performance evaluation for municipalities that implemented PMAT, containing 70 descriptors linked to 14 critical points of view, organized in four areas of interest, and consistent with the characteristics and objectives required by the program.
\end{abstract}

KEYWORDS: Performance Evaluation. Public Management. Municipal Tax Administration. MCDA-C Methodology.

\section{AVALIAÇÃO DE DESEMPENHO DOS MUNICÍPIOS BRASILEIROS A PARTIR DA IMPLANTAÇÃO DO PROGRAMA DE MODERNIZAÇÃO DA ADMINISTRAÇÃO TRIBUTÁRIA - PMAT}

\footnotetext{
* Ademar Dutra, Professor in the Master Program - Management at the University of Southern Santa Catarina - UNISUL. Doctor in Production Engineering and Systems at UFSC. 219 Trajano Street, room 1201- Florianópolis - SC- Brazil.Email: ademar.unisul@gmail.com

Ana Paula Adriano Platt, Master in Management, Department of Applied Social Sciences of University of Southern Santa Catarina - UNISUL

1487 Mauro Ramos Avenue, apt 1308 - Florianópolis - SC.

Email: ana.paula.adm@hotmail.com

Sandra Rolim Ensslin, Professor in the Doctoral Program in Accounting at the Federal University of Santa Catarina - UFSC. Doctor in Production Engineering and Systems at UFSC.

41 Itararé Street - Florianópolis - SC.

Email: sensslin@gmail.com

Vicente Mateo Ripoll-Feliu, Professor in the Accounting Department of Valencia University - Spain.

Doctor in Accounting at Valencia University.

Los Naranjos Avenue 46022 Valencia.

Email: vicente.ripoll@uv.es

Jacir Leonir Casagrande, Professor in the Master Program in Management at the University of Southern Santa Catarina - UNISUL. Doctor in Production Engineering and Systems at UFSC

219 Trajano Street, room 1201- Florianópolis - SC - Brazil.

Email: jacir.casagrande@unisul.br
} 


\section{RESUMO}

O Governo Federal disponibilizou aos municípios brasileiros o PMAT com o objetivo de modernizar e fortalecer a administração tributária. Por se tratar de recursos públicos, tornase necessária a implementação de medidas para o controle da aplicação dos investimentos do Programa. O objetivo desta pesquisa é propor um modelo de avaliação de desempenho para os municípios que implantaram o PMAT, onde se pretende: (i) identificar os objetivos, características e critérios exigidos pelo PMAT para habilitar as Prefeituras Municipais na obtenção dos recursos; (ii) definir os critérios necessários para compor a estrutura do modelo de avaliação de desempenho dos municípios a partir da implantação do PMAT; (iii) determinar os parâmetros de julgamento para permitir a avaliação dos municípios. Para alcançar os objetivos de pesquisa foi realizado um estudo exploratório, com abordagem qualitativa/ quantitativa. Os dados foram coletados com entrevistas semi-estruturadas. Como resultado da pesquisa propõe-se um modelo de avaliação de desempenho para os municípios que implantaram o PMAT, contendo 70 descritores, vinculados a 14 pontos de vista fundamentais, organizados em 4 áreas de interesse, e compatível com as características e objetivos exigidos pelo Programa.

PALAVRAS-CHAVE: Avaliação de Desempenho. Gestão Pública. Administração Tributária Municipal. Metodologia MCDA-C.

\section{INTRODUCTION}

The state reform initiatives that took place in many countries for more than thirty years have become more apparent from the 1990s when the public administrations of several countries began to worry about the use of specific methodologies to assess the performance of public programs, with the aim of making more efficient the government structure (Teixeira and Santana, 1995).

However, this expected improvement could only be achieved with the use of appropriate tools that can monitor and evaluate the performance of the state apparatus, especially in relation to programs and public projects focused on social matters. (FAVERO, 2010)

The need for the use of appropriate tools for assessing the performance of the state apparatus has become recognized worldwide and thus, many countries in all regions have developed methods and tools they thought ideal to track progress and the quality of public services.

In Brazil, the measures taken to control and modernize the performance of Public Administration started with the implementation of the Management Program of State Enterprises (PGE), established by the Federal Government in 1991 with the objective of promoting the efficiency and competitiveness of these companies (FEDERAL DECREE 137, 1991).

During the nineties, the Brazilian Government in a management-by-results perspective, introduced the management model implemented from the state apparatus reform, focusing on planning tools, budget and management, represented by the integration of the Multiannual Plans (PPA) developed for periods of four years and the Annual Budgets (NADER, 2005).

In May 2000 the Brazilian Government enacted the Fiscal Responsibility Law (FRL) in order to ensure greater responsibility and transparency to the actions of public 
administrators in the three spheres of government - federal, state and municipal. The FRL provided to society greater confidence in relation to the collection and application of tax revenues (KHAIR, 2001).

In this scenario, the federal government began to engage efforts in order states and municipalities could take advantage of this period of greater social credit to modernize themselves in accordance with the principles of the new management model that was installed in the country. This set of changes in public administration provided the improvement of responsible fiscal management of public resources, through planned and transparent action which made possible risk prevention and correction of deviations that may affect the balance of public accounts.

Like any process of modernization, that time that faced states and municipalities required besides action planning, greater availability of financial resources. Aware of this reality of change in public management model that occurred in the three spheres of government, the federal government woke up to the need to assist the states and municipalities in strengthening their management skills, by strengthening its income and the modernization of tax administration.

With regard to the municipalities, the federal government introduced in September 1997, through the National Development Bank (BNDES), the Program for Modernization of Tax Administration (PMAT), which aims to ensure conditions of greater managerial, administrative and financial autonomy to Brazilian Municipalities.

PMAT allows municipalities to become financially independent through measures that prioritize the fair taxation and the increase of tax collection from their taxes. There is broad consensus that the PMAT contributes to the development of the municipalities. However, the scope of the program's objectives should be monitored by the municipalities that use these resources in order to convert these results into effective actions in the interests of society (http:/ / www.bndes.gov.br).

This study has the objective to propose a performance evaluation model for Brazilian municipalities that implemented the PMAT, based on Multicriteria Decision Aid Methodology - MCDA-C, which allows the City halls to identify the achieved results toward the goals established by the Program.

The scope of the overall objective will be pursued through the following specific objectives: i) identify the objectives, characteristics and criteria required by PMAT to enable municipal governments in obtaining resources; (ii) define the criteria necessary to compose the structure of the performance evaluation model of the municipalities from the implementation of the PMAT and; (iii) determine the criteria of judgment criteria to allow the evaluation of municipalities.

The relevance of this research lies on building a tool for monitoring the use of public resources through the application of a methodology capable of generating knowledge for public administrators for the BNDES and the population seeking improvement in municipal public administration.

\section{PERFORMANCE EVALUATION IN PUBLIC ADMINISTRATION}

The contemporary scientific production in Brazilian Public Administration has some works considered classics that have helped in achieving the trajectory of studies and research that aim to broaden and enhance the field of the Brazilian public administration (MACHADO-DA-SILVA, AMBONI E CUNHA, 1989; FISCHER 1984; KEINERT and LAPORTA, 
1994). Souza and Araújo (2003), mapped authors linking to their researched topics, systematizing a study of the public management field literature within focus dimension, used by Keinert (2000). There are five:

(i) a first post-bureaucratic focus, detailing the main aspects of novations and new management practices, along with the managerial movement, understood as a postbureaucratic trend. It is emphasized that, in part, this post-bureaucratic trend takes some assumptions and focus from political science, which has been notably advocated by authors like Barzelay (1994), Abrucio (1997), Bresser Pereira (2008, 2009), Bresser Pereira; Spink (2001).

(ii) the second focus, addresses the impacts of globalization in the Brazilian state apparatus and in some countries, those which have made the so-called structural reforms, in the State and public administration. It analyzes and evaluates the main impacts of economic globalization in the managerial capacity of governments advocating the expansion of governance and institutional capacities suggesting and proposing policies and deregulation programs, privatization of the State through privatization and flexibility of public organizations (KOUZMIN, 1998; FARMER 1998; HAQUE, 1998).

(iii) the third focus addresses the conditioning factors of political, economic and social order, which criticizes the type of insertion of Brazil in the globalized world economy, without considering regional and local aspects, adding itself to the import of economic models and private management practices, disconnected from the Brazilian social reality.

(iv) the fourth focus refers to the new trends in public policies cycle. Increasingly, it is emphasized the issue of public policies, particularly in Brazil, as an important instrument for income distribution and social reintegration for the poorest segments. In this focus, it has been observed a relevance of more neo-institutionalist studies exploring the role, nature and the importance of institutions and State-society, politicians and bureaucrats, citizens and government and State- public administration relations. The main hub of this focus is the question of the relationship between the economy and the public administration where the government urgently needs to define a management policy that, in addition to economic issues, can articulate development and economic growth, with democratization and transparency of actions state, with social control over public administration. Mello (2002) is an important author in this field.

(v) the fifth focus is concerned with the management of social policies in Brazil and Latin American continent. With the increase of poverty in our continent and especially in Brazil, including the precarious labor relations and the lack of workers' professional qualifications, just forced governments to prioritize the development and implementation of more emancipatory and income redistribution social policies. Authors such as Dowbor (1998), Fleury (2003) among others, are notably some of the most important researchers in the management of social policies in Brazil.

To measure organizational performance in managerial public administration, the focus was displaced from the processes to the results, which leads to the need for change in public sector culture to another culture focused to society, creating a flexible and freedom structure so that the objectives are achieved. The result is a direct product of the process and concerns to products and services that must occur outside the process.

Teixeira and Santana (1995) point out that the process of public administration modernization concerned with the results, established a new dynamic in the public sector, with the application of indicators systems that facilitate the identification of objectives and 
goals to be achieved. Thus, the performance evaluation is a management legitimation and rationalization tool in order to have a monitoring and evaluation by society.

In an ideal system of performance evaluation, the complexity of information - from data as resources and materials to the results and impact - would be used by public managers within a logic in which the link between performance monitoring (of processes, efficiency and production) and the evaluation of the performance (results and impacts) would be used to guide the strategic planning of a program and enhance its performance in the future (FAVERO, 2010).

In the sphere of the public administrations, the concern with devoting time, knowledge and other resources for the implementation of methodologies that aim to assess the performance of social and public programs made its mark from the administrative reform trends introduced in the public administration the managerial administration mode (COSTA; CASTANHAR, 2003).

Thus, State reform initiatives that took place in many countries for more than thirty years ago aimed to make the structure of government work better and at lower cost. However, this improvement could only be observed with the implementation of tools that would allow monitoring the performance of the state apparatus mainly represented by its public and social programs (KETTL, 1998).

In the 1990s, the need to use appropriate tools for the apparatus' performance evaluation has been recognized in all regions of the world, when many countries are started developing methods and tools that thought ideal to track the progress of public and social programs.

In Brazil, the first measure adopted to control and modernize the intrinsic activities of public administration was implemented by Decree No. 137 of 1991, which established the Program for Management of State Enterprises (PGE). This program intended to promote efficiency and competitiveness of state enterprises through a set of guidelines aimed at harmonizing the management of these companies with the economic policy of the country.

Within the new perspective of management by results, the managerial model implemented from the State Apparatus Reform had as its core idea the integration of planning instruments, budget and management that should be organized in three time horizons: an eight-years strategic which would indicate the integration of the Multi-annual plans (PPA) for four years and annual budgets (NADER, 2005).

At every reissue that used to happen at every four years, the management model implemented in Brazil with the support of the PPA passed changes that made the program more consistent and showing increasingly satisfactory results on the management and control of public actions (NADER , 2005).

Initially the program had as main focus the sustainable development of the country and therefore it prioritized actions such as reducing costs and expanding the competitiveness of the economy, the reduction of social and regional disparities, enabling greater private investments and the viability of public-private partnerships (Brazil: MP / SPI, 2002).

Subsequently, the Ministry of Planning, Budget and Management of Brazil added some concepts to the program management methodology in order to ensure more quality in its management. These improvements were more incisive regarding the establishment of measures for evaluating the program performance as a whole. The need to make the state 
increasingly turned to the results that transfers to the society becomes latent before public administrators.

Thus was established the Evaluation System of Multi-Year Plan, consisting of a Monitoring and Evaluation of the Multi-Annual Plan Commission (CMA) and Monitoring and Evaluation Units (UMA) (http:// www.planejamento.gov.br).

The Commission for Monitoring and Evaluation (CMA) plays a key role in the success of the Multi-Annual Plan Evaluation System featuring a number of responsibilities as the establishment of general guidelines for the implementation of methodologies for evaluating the programs, the selection of programs that will be object of specific evaluation, the monitoring of program evaluations set developed by sectorial bodies, among others (http:// www.planejamento.gov.br).

With so many assignments, the CMA is considered the driving force for the Monitoring and Evaluation System (SMA) correct performance and thus it stimulates the implementation of public policies through an integrated view determined by the search for continuous improvement of processes inherent to the cycle of the Plan management and its interface with the performance of the Central Bodies of the Planning and Budget System of the Federal Government.

Another initiative of the Federal Government to establish a new management culture where citizens are included in the application monitoring process of public resources and evaluation of its results was the establishment of the Fiscal Responsibility Law.

The Fiscal Responsibility Law (FRL) was published in May 2000 in order to enhance the responsibility on fiscal management of public resources, through planned and transparent action that enables to prevent risks and correct deviations that may affect the balance of public accounts. There are assumptions of LRF, transparency, control and accountability.

Transparency, according Khair (2001, p.15) is implemented with the wide disclosure of four new monitoring reports (including the internet) on fiscal management, identifying the revenue and expenditure: "Attachment of Fiscal Goals; Attachment of Fiscal Risks; Summary Report of the Budget Execution and Fiscal Management Report ".

According Khair (2001, p.14), "the control is facilitated by the creation of new fiscal management monitoring reports that, besides mandatory publication shall be made available on the Internet." Moreover, adds the author, to be established in each public entity a Board of Tax Management, formed by the government and civil society, for the monitoring and ongoing evaluation of policy and operability of fiscal management.

Accountability should occur whenever there is noncompliance with the rules.

Fiscal irresponsibility could result in the suspension of voluntary transfers, guarantees and credit operations contracting, including ARO. The responsible will suffer the penalties prescribed by Law 10,028 / 2000 dealing with fiscal responsibility crimes.

From LRF main objectives to ensure greater accountability and transparency to the actions of public administrators, it increased confidence of society in relation to the application of the revenue collected through taxes. Thus, the Federal Government itself began to commit efforts in order States and municipalities could take advantage of this period of greater social credit to modernize themselves in accordance with the principles of the new management model that was installed in the country. 
Like any process of modernization, the Brazilian states and municipalities demanded a process of planning their actions and the availability of financial resources. Aware of this reality, the Federal Government has made available to both Brazilian municipalities as states some modernization programs of the Tax Administration, among them the PMAT, in order to allow these levels of government also have conditions to strengthen their own revenues and consequently provide quality services to the population through a new results-based management.

\section{RESEARCH METHODOLOGY}

From a methodological point of view, this research is: (i) qualitative / quantitative, regarding the methodological approach; (ii) exploratory, regarding the objective; and (iii) a case study, regarding the strategy.

Regarding the methodological approach, the framework of this research as qualitative / quantitative follows the precepts recommended by Merriam (1998), who states that qualitative research defends the interest in understanding the meaning of sensations and feelings experienced by human experience, while quantitative research makes use of statistical and mathematical tools as a working tool.

With regard to the objectives, this work is considered exploratory due to its characteristic of seeking a closer relationship with the object of study. According to Gil (1991, p.45) this type of research "has the objective to provide greater familiarity with the problem, in order to make it more explicit or build hypotheses".

Regarding the framework of the strategy, we defined this research as a case study, since the intention of the researcher is to seek an object of study in depth, taking into account the context in which it appears. Thus, Santos (2001) states that the case study consists of selecting a single or few research objects that might be deepening.

The information used in the development of this research was obtained through semi-structured interviews and documentary analysis, which allowed researchers to achieve the objectives initially proposed.

As an intervention instrument for the purposes of this research, we used the Multicriteria Constructivist Decision Aid Methodology - MCDA-C. This methodology has its origin from a branch of Operational Research, science that uses ready mathematical models and excellent results, called Soft PO (DUTRA, 1998).

To Dutra (1998, p. 161), within the Soft PO is still possible to observe the formation of two major schools of thought, the "American School of Decision Making, called MCDM and the European School of Decision Aid, called MCDA" .

The intervention methodology used in the development of this research follows the premises developed by the European School current, called Multicriteria Constructivist Methodology Decision Aid - MCDA-C. The use of MCDA - C occurs in three different and complementary phases: (i) structuring; (ii) evaluation; and (iii) recommendations, as shown in Figure 1 (AZEVEDO et al, 2013; DUTRA et al, 2014; ENSSLIN et al, 2014; MARAFON et al, 2015).

In structuring phase, the first step involves obtaining information about relevant aspects of the analyzed context, the identification of the actors involved and the definition of a label for the problem. 
The second stage of this phase includes the identification of Evaluation Primary Elements (EPAs) that reflect the considerations of decision-makers in relation to their "objectives, goals and values," to solve the problem (Bana and Costa cited Ensslin, Montibeller and Noronha 2001 , p. 79).

After identifying the EPA's their concepts are defined, in order to make clear the intention of the decision-maker with respect to each of the elements he established (COSTA et al, 2008). Following, the facilitator should separate the EPA's and its concepts by areas of interest to ranking priorities, so that the concepts related to the end objectives are allocated on the top and the means concepts are provided below their respective end concepts. This process generates new concepts that along with previous concepts form cognitive maps for the model (ENSSLIN, ENSSLIN, S. and CARPES, 2004).

The third step consists of the use of decomposition logic to define the Essential Points of View, Elementary Points of View and Descriptors that form the tree structure for the model. The definition of descriptors enables you to measure the performance of each Point of View that makes up the model (COSTA et al, 2008; DUTRA et al, 2014).

Figure 1 - Phases of MCDA-C Methodology

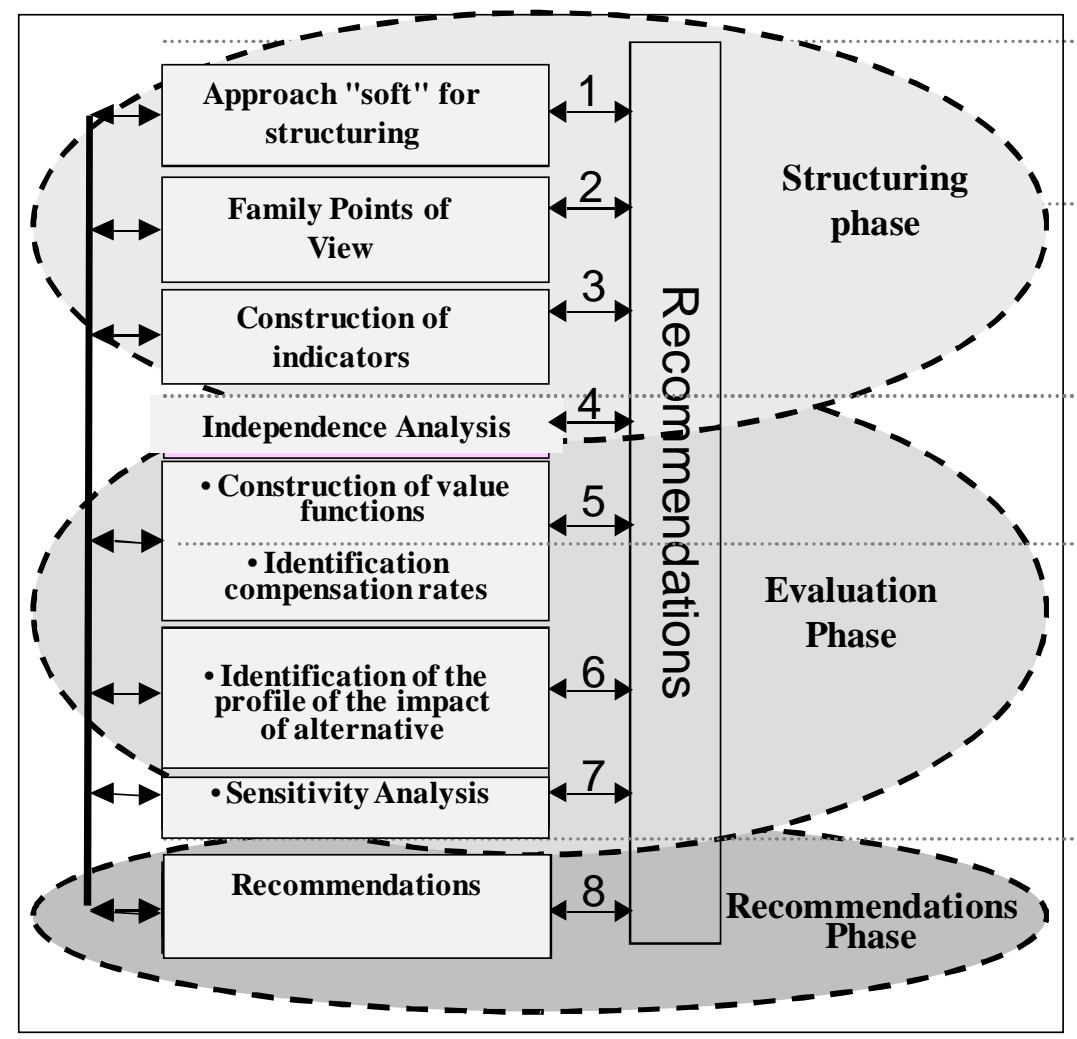

Source: Adapted from Ensslin, Dutra, Ensslin, (2000).

In the evaluation phase is considered at first the construction of value functions for each descriptor to allow measurement of the actions implemented performance in each Point of View. Thus, noted Costa et al (2008, p.10), "you need to assess the attractiveness of decision-makers at the various descriptor impact levels." 
After the construction of the value function is necessary to define the replacement rates. According to Dutra (1998) value function construction has the purpose of ordering the intensity of preference while replacement rates report the amount of performance that an action should gain to compensate for the loss of performance in another, and in this way can perform aggregation of PVFs providing an overall assessment.

The third phase, Recommendations intended to draw up suggestions for enhancement in order to improve the organization's performance and / or context that was previously evaluated.

\section{RESULTS}

Despite the relevance of applying the three phases of the MCDA-C methodology, this study will address only the structuring phase and part of the evaluation phase, since the objective of this research is the development of PMAT's performance evaluation model, not including the application of the proposed model in municipal city halls.

The quest for efficiency in public management is possible only through the implementation of performance evaluation measures used systematically and continuously. Therefore, monitoring of PMAT results is relevant to public administrators to identify the factors that affect the performance of its activities, correcting any discrepancies limiting public policy.

Whereas the model to be developed for the performance evaluation of the municipalities from the PMAT implementation is supported in MCDA-C methodology, begins the structuring phase with the identification of the actors involved in the decision-making process, as follows: decision-maker: consultant specializing in the implementation of PMAT in Brazilian cities; (ii) Intervenient: public managers; (iii) facilitators: authors of this paper; (iv) acted: public servers and population.

Subsequently, it was set up a label for the object problem of this study, which is to propose a performance evaluation model for Brazilian municipalities from the implementation of the PMAT. Through semi-structured interviews with the decision maker EPAs considered important were identified in order to structure the performance evaluation model. Following concepts were formulated for each EPA in order to guide the decisionmaker in identifying the actions used as a parameter in the construction of cognitive maps.

In the table 1 we can see examples of EPAs and their concepts, which were identified in this case study.

Table 1 - Examples of EPAs and concepts

\begin{tabular}{|c|l|l|}
\hline № & \multicolumn{1}{|c|}{ EPA } & \multicolumn{1}{c|}{ CONCEPT } \\
\hline 1 & Increased Tax Collection & $\begin{array}{l}\text { Increase collection of municipal taxes ... not increase tax } \\
\text { collection }\end{array}$ \\
\hline 2 & $\begin{array}{l}\text { Reduction of Transfers } \\
\text { dependency }\end{array}$ & $\begin{array}{l}\text { Reduce financial dependence on government transfers, } \\
\text {..not reduce financial dependence }\end{array}$ \\
\hline 3 & $\begin{array}{l}\text { Projects for increase in } \\
\text { tax revenues }\end{array}$ & $\begin{array}{l}\text { Implement projects for the reduction of tax evasion and } \\
\text { increase tax revenues ... not implement projects that } \\
\text { optimize the municipal collection. }\end{array}$ \\
\hline 4 & Tax Substitution & $\begin{array}{l}\text { Implement tax substitution system to increase revenue } \\
\text {... not implement the tax substitution system }\end{array}$ \\
\hline
\end{tabular}

Source: Elaborated by the authors, 2012 
Later, the EPAs are grouped in areas of interest to facilitate the model view that intends to establish, as shown in Figure 1.

The 72 EPAs shown in Figure 2 are organized in the areas of interest: Processes, Modernization, Collection and People.

Following cognitive maps are constructed which are graphical representations where each concept raised in the previous step is regarded as the node that has links with other nodes due to influences relationships between them (ENSSLIN; MONTIBELLER; NORONHA, 2001; DUTRA et al, 2014)

Figure 2 - EPA grouped by areas of interest

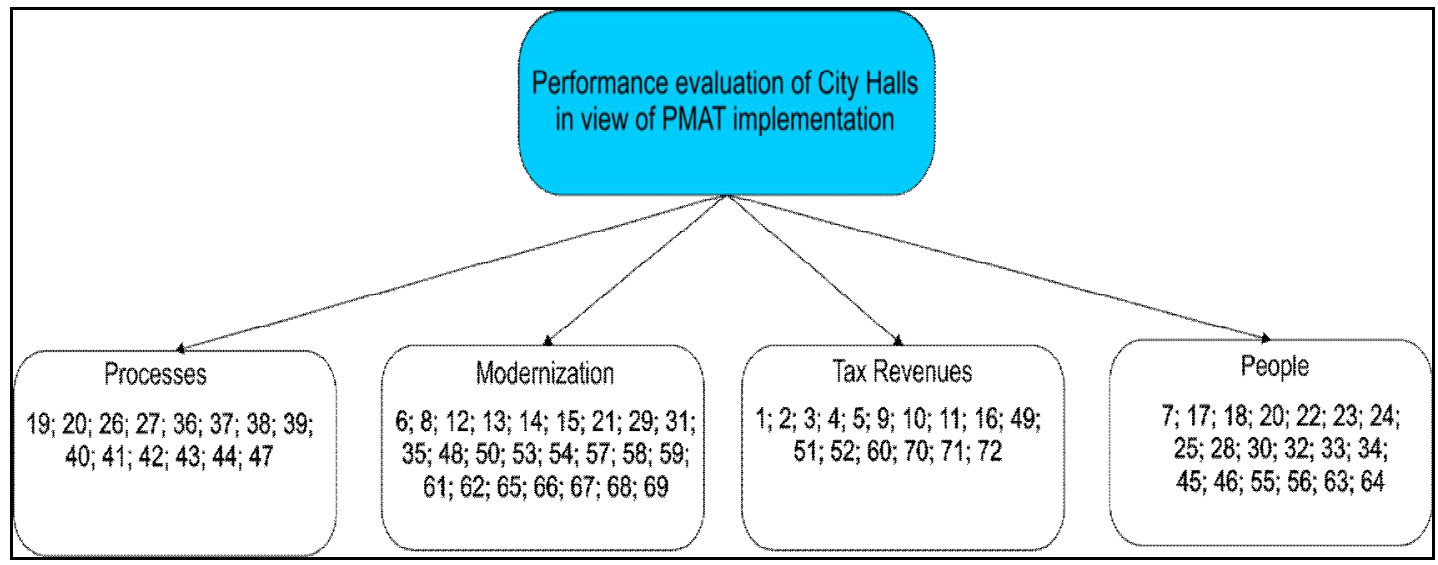

Source: Elaborated by the authors, 2012

After constructed cognitive maps we part to the systematization of the hierarchy value structure that is formed by the Essential Points of View (PVFS) and their respective descriptors. When the measurement of a PVF not occur directly due to reflect qualitative aspects, it is necessary its decomposition in Elementary Points of View.

After the decomposition process of PVFS, the descriptors are defined to allow the measurement of the criteria considered when evaluating the model. This process was carried out for all PVFS, resulting in the construction of the complete value hierarchical structure of the performance evaluation model, as shown in Figure 3.

Figure 3 which shows the value hierarchy structure for Modernization area of interest, is composed by 3 PVFS to be operated through 16 descriptors.

In the evaluation phase (MCDA-C methodology) the main objective is to determine the local cardinal scales through the value function and set parameters to add the particular performance of a set of criteria in a single value, through the replacement rates (COSTA et al, 2008; MARAFON et al, 2015).

The value function determines the difference of attractiveness between impact levels of the same descriptor. For its construction the decision maker analyzes each descriptor individually and determines how attractive a level of performance is when compared to another level. The construction of the value function is performed with Macbeth software support, is shown in Figure 4. 
Figure 3 - Value Hierarchical Structure Value for Modernization Area of Interest

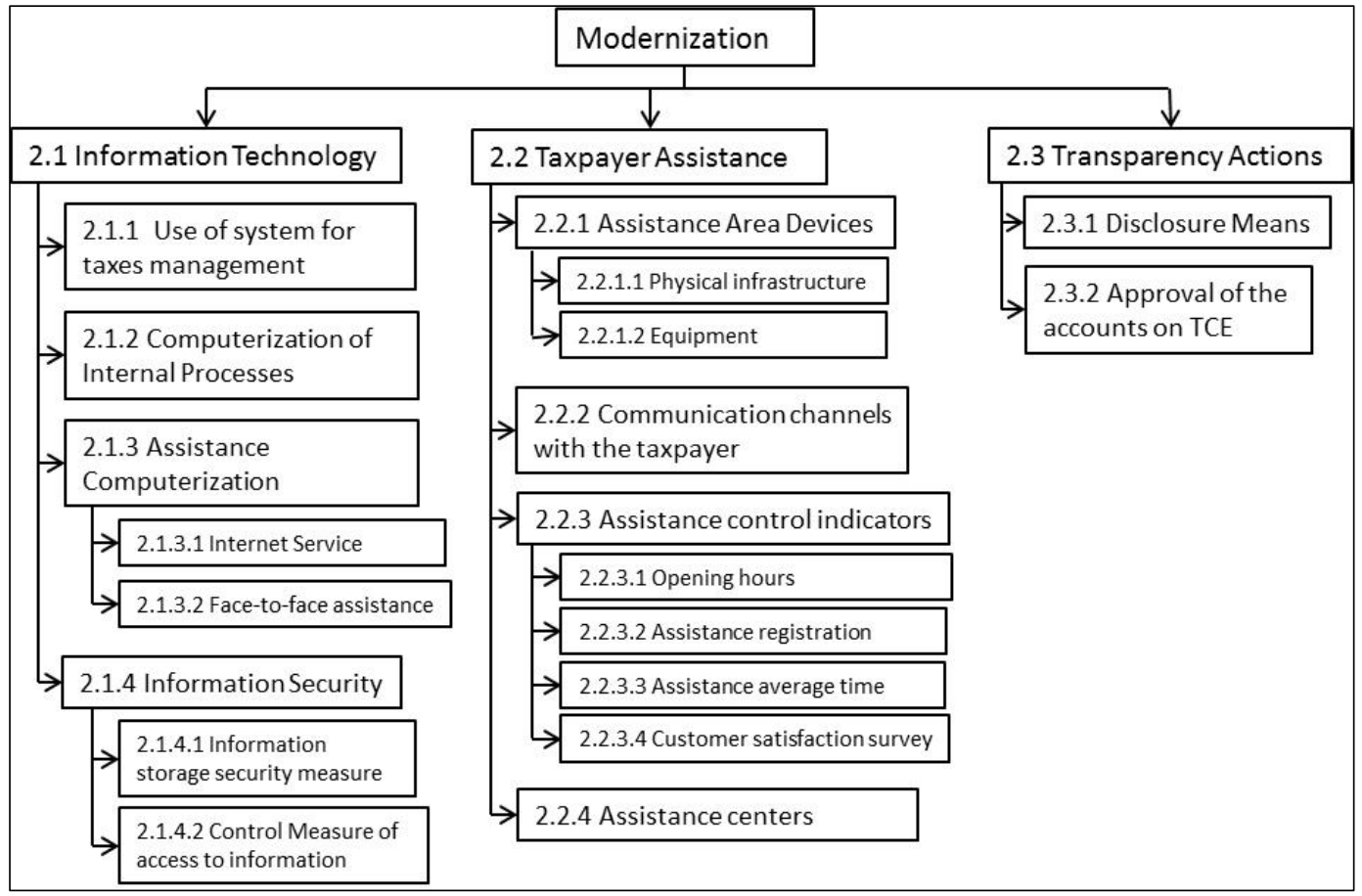

Source: Elaborated by the authors, 2012

Figure 4 - Value Function for Descriptor Property Tax (IPTU) Collection Increase

\begin{tabular}{|c|c|c|c|c|c|c|}
\hline 圆 & N3 & N2 & N1 & NO & $\begin{array}{c}\text { Currente } \\
\text { Scale }\end{array}$ & Extreme \\
\hline N3 & Null & Strong & Very Strong & Extreme & 100.0 & Very Strong \\
\hline N2 & & Null & Strong & Very Strong & 500 & Strong \\
\hline N1 & & & Null & Very Strong & & Moderated \\
\hline & & & & & & Weak \\
\hline Nou & & & & IVuil & -62.5 & Very Weak \\
\hline \multicolumn{6}{|c|}{ Consistent Judgements } & Null \\
\hline 聿 & & & 里 & 菂 & 60 & 임 \\
\hline
\end{tabular}

Source: Elaborated by the authors, 2012

After the alternatives attractiveness judgment, the decision maker is responsible for setting the anchors levels for each descriptor, determining a "neutral" performance, and other "good" compared to the analyzed descriptor. The "good" and "neutral" anchors levels feature score 100 and 0 , respectively, for these levels have the same degree of attractiveness in any model descriptor, allowing the performance additive aggregation process. 
The definition of replacement rates contributes to the additive aggregation of the continuous points of views in the hierarchical structure of the model value, allowing the construction of a tool for the overall assessment of the performance of municipalities that implemented the PMAT.

The first step towards construction of replacement rates is the criteria ranking according to the degree of importance they represent to the model in the perception of the decision maker. In the systematization of the criteria ordering process was used Roberts' Matrix (1979).

To identify replacement rates in MACBETH software, related information is introduced in the ordering performed previously and asks the decision maker to judge together with potential actions. This procedure was performed for all the performance evaluation model of municipalities that implemented the PMAT. The Figure 4 represented below shows the complete value hierarchy structure for the Modernization area of interest and replacement rates determined for each Poin of View that compose it.

Figure 5 - Value Hierarchy structure Modernization area of interest and respective replacement rates

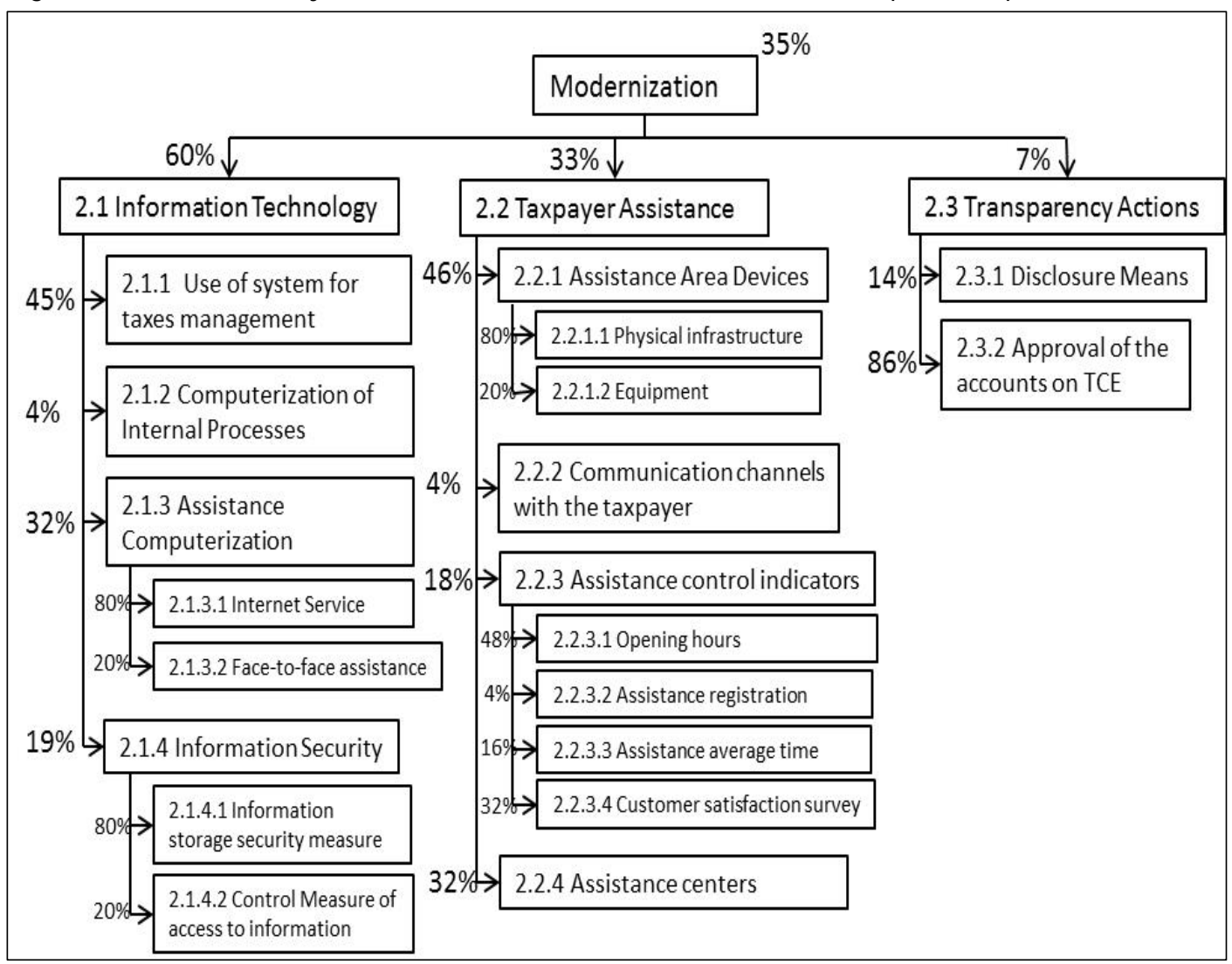

Source: Elaborated by the authors, 2012

After this step, it is concluded the elaboration process of performance evaluation model of municipalities that implemented the PMAT, which were obtained four major areas of interest: Processes, Modernization, Collection and People; 14 Essential Points of View; and 70 descriptors. 
The constructed model of PMAT performance evaluation for municipalities of Santa Catarina meets the assumptions of managerial public administration, which focuses on the results of public management (TEIXEIRA and SANTANA, 1995; COSTA and CASTANHAR, 2003; BRESSER PEREIRA, 2008, 2009; FAVERO, 2010).

\section{FINAL CONSIDERATIONS}

The Modernization Program of the Tax Administration (PMAT) instituted in 1997 by the Federal Government in order to promote the strengthening of revenue and the modernization of the treasury area of Municipalities, since its institution had great impact among Municipalities that joined the implementation. The good acceptance to the program by municipalities is evidenced in the fact that by the year 2009, approximately R $\$ 572$ million of funds were released by BNDES for the financial strength and administrative modernization of Municipal Treasuries. As they are public resources, its use must be followed and the results monitored through a tool able to assess the results obtained by the Municipalities in the face of the goals previously established by the Program.

This paper aims to propose a performance evaluation model for Brazilian municipalities that implemented the PMAT, based on Multicriteria Decision Aid Methodology - MCDA-C.

The MCDA-C methodology MCDA-C is developed in three phases that complement each other, which enable integration in one model of objective and subjective nature elements as well as the participation of the actors involved. The study was restricted to structuring phase and starts from the evaluation phase, given the objective of proposing a performance evaluation model for municipalities without, however, intending to test its applicability in a particular case.

As evidenced, the structuring phase of the model included the formation of four major areas of interest, 14 essential points of view and 70 descriptors, identified from the Cognitive Maps.

It can be concluded that this study achieved its objective to propose a performance evaluation model for municipalities that implemented the PMAT, which if used by the Municipalities will allow to compare the results achieved in the face of the goals previously established by the Program.

In a broader view, the proposed performance evaluation model becomes an enabler instrument of modernization of public administration and financial autonomy of municipalities, enabling Municipalities provide more services to the society with higher quality.

It is recommended for future research the application of performance evaluation model proposed in this work in other Municipalities that used the resources of the PMAT and the compatibility of the model structure with the perception of the creators of PMAT and BNDES. 


\section{REFERENCES}

ABRUCIO, Fernando Luiz. O impacto do modelo gerencial na Administração Pública: um breve estudo sobre a experiência internacional recente. Brasília: ENAP, Cadernos ENAP, n.10. 1997.

AZEVEDO, R. C., LACERDA, R.T.O., ENSSLIN L., JUNGLES, A. E., ENSSLIN, S.R. Performance Measurement to Aid Decision Making in the Budgeting Process for Apartment-Building Construction: Case Study Using MCDA-C. Journal of Construction Engineering and Management. V.139, p.225-235, 2013.

BARZELAY, Michael. Breaking through bureaucracy. Berkeley: University of California Press, 1994.

BRASIL, Decreto № 137 de 27 de maio de 1991. Institui o Programa de Empresas Estatais. Disponível em 〈http/ / www.planejamento.gov.br〉 Acesso em 16 de março de 2011.

BRASIL, Secretaria de Planejamento e Investimentos Estratégicos do Ministério do Planejamento, Orçamento e Gestão (2003), Relatório Anual de Avaliação do Plano Plurianual 2000-2003 - Ano Base 2002. Brasília: SPI - MP.

BRESSER PEREIRA, L. C.; SPINK, P. K. Reforma do Estado e Administração pública gerencial. 4. ed. Rio de Janeiro : FGV, 2001.

BRESSER PEREIRA, L.C. Construindo o Estado republicano: democracia e reforma da gestão pública. Rio de Janeiro: Editora FGV, 2009.

BRESSER PEREIRA, L.C. O modelo estrutural de gerência pública. Revista de administração pública da Fundação Getúlio Vargas. Rio de Janeiro, n. 42 pp. 391-410, mar./ abr. 2008.

COSTA, F. L. A.; CASTANHAR, J. C. Avaliação de programas públicos: desafios conceituais e metodológicos. RAP, Rio de Janeiro, set./ out. 2003.

COSTA, J. M.; BORGET, A.; SCHULTZ, C. A.; PEREIRA, M. F. Desempenho Agregado: A construção de um modelo de avaliação. XXVIII Encontro Nacional de Engenharia de Produção. Rio de Janeiro, 13 a 16 de outubro de 2008.

DOWBOR, Ladislau. A reprodução social. São Paulo: Editoras Vozes, 1998.

DUTRA, A. Elaboração de um sistema de avaliação de desempenho dos recursos humanos da Secretaria do Estado da Administração - SEA à luz da MCDA. 1998. Dissertação (Mestrado) Programa de Pós-graduação em Engenharia de Produção, Universidade Federal de Santa Catarina, Florianópolis, 1998.

DUTRA, A., GAMBA JUNIOR, J., FELIU, V. M. R., ENSSLIN, S.R., LACERDA, R. T. O. Multicriteria Performance Evaluation of Emergency Service Conducted by Military Fire Department in Santa Catarina - Brazil. La Pensée (Paris), v. 76, p. 94-108, 2014.

ENSSLIN, L.; ENSSLIN, S. R.; CARPES, M. M. M.. A identificação da repercussão da incorporação da responsabilidade social na gestão organizacional por meio da Metodologia MCDA-Construtivista. In: ENEGEP, 2004, Florianópolis. XXIV Encontro Nacional de Engenharia de Produção. Porto Alegre-RS : ABEPRO-Edições, 2004. v. Unico. p. 1-8.

ENSSLIN, L; MONTIBELLER, G.; NORONHA, S. Apoio à decisão: metodologias para estruturação de problemas e avaliação multicritério de alternativas. Florianópolis: Insular, 2001. 
ENSSLIN, Leonardo, DUTRA, Ademar, ENSSLIN, Sandra R. MCDA: A constructivist approach to the management of human resources at a governmental agency. International Transactions in Operational Reseach (Intl.Trans.in Op. Res.) IFORS - Published by Elsevier Science Ltd. ISBN 0969-6016/ 00, v.7, p.79-100, 2000.

ENSSLIN, S.R., DUTRA, A., Duarte, C. S., BORTOLUZZI, S. C., RIPOLL-FELIU, V. M. A avaliação de desempenho como proposta para gestão das equipes do programa brasileiro Estratégia da Saúde da Família (ESF). Revista gerencia y politica de salud, v. 13, p. 10-25, 2014.

FARMER, David John. Schopenhauer's porcupines: hegemonic change in context. In: Administrative Theory \& Praxis, v. 20, n² 4, pp. 422-433, dec., 1998.

FAVERO, C.G. Avaliação de Programas Públicos. Sistema de Avaliação do Programa Nacional de Gestão pública e Desburocratização Aplicado a Marinha do Brasil - O caso do Programa Netuno. Dissertação de Mestrado em Administração Pública. Fundação Getúlio Vargas, Rio de Janeiro, 2010.

FISCHER, Tânia. Administração pública como área de conhecimento e ensino: a trajetória brasileira. In: Revista de Administração de Empresas. Rio de Janeiro, v. 24,n 4, pp. 278-88, 1984.

FLEURY, Sonia (Org.). Análise do perfil dos artigos publicados na Revista de Administração Pública - RAP - no período 1992-2002. Rio de Janeiro: Editora EAESP/ FGV, 2003.

GIL, A.C. Como elaborar projetos de pesquisa. São Paulo: Editora Atlas, 1991.

HAQUE, M. Shamsul. Impacts of globalization on the role of the State and bureaucracy in Asia. In: Administrative Theory \& Praxis, v. 20, nº 4, pp. 439-451, dec., 1998.

KEINERT, Tânia M. M. Administração pública no Brasil: crises e mudanças de paradigmas. São Paulo: Editora Annablume: Fapesp, 2000.

KEINERT, Tânia M. M. e LAPORTA, Claúdio B. A RAP e a evolução do campo de administração pública no Brasil (1965-92). In: Revista de Administração Pública. Rio de Janeiro, v. 28, n 1, pp. 5-17, 1994.

KETTL, D. F. (1996) A revolução global: reforma da administração do setor público. In: BRESSER-PEREIRA, Luiz Carlos; SPINK, Peter. Reforma do Estado e Administração Pública gerencial. Rio de Janeiro: FGV, 1998.

KHAIR, A. A. Lei de Responsabilidade Fiscal: guia de orientação para as prefeituras. Brasília: Ministério do Planejamento, Orçamento e Gestão/ BNDES, 2000.

KOUZMIN, Alexander. Symposium: globalization and public administration - enhancing dismantling or protecting distinctive administrative capacity? In: Administrative Theory \& Praxis, v. 20, n² 4, pp. 434-438, dez., 1998.

MACHADO-DA-SILVA, Clóvis L.; AMBONI, Nério e CUNHA, Vera. Produção acadêmica em administração pública: período 1983-88. In: XVIII EnANPAD, Belo Horizonte/ MG, 1989. Anais ...

MARAFON, A. D.; ENSSLIN, E.; LACERDA, R. T. O.; ENSSLIN, S. R.(2015), The effectiveness of multi-criteria decision aid methodology: A case study of $R \& D$ management. European Journal of Innovation Management, Vol. 18 No. 1, 2015, pp. 86-109. http:/ / dx.doi.org/ 10.1108/ EJIM10-2013-0106.

MELLO, Marcus André. Reformas constitucionais no Brasil: instituições políticas e processo decisório. Brasília/ DF: Editora REVAN, 2002. 
MERRIAN, S.B. Qualitative research and case study applications in education. San Francisco: Jossey-Bass Publisher, 1998.

NADER, R. M. A avaliação como ferramenta para uma gestão pública orientada para resultados: o caso do Governo Federal Brasileiro. Caracas, 2005. Disponível em<http/ / www.clad.org.ve>Acesso em 15 mai. 2010.

ROBERTS, S. F. Three Representation Problems: Ordinal, Extensive, and Difference Measurement. In: Rota, Gian-Rota. Encyclopedia of Mathematics and Its Applications. Measurement Theory, v. 7, p. 101-147, 1979.

SANTOS, A.R. Metodologia Científica: a construção do conhecimento. Rio de Janeiro: DP\&A editora, 2001.

SOUZA, Antonio Ricardo de e ARAÚJO, Vinícius de Carvalho. O estado da reforma: balanço da literatura em gestão pública. In: Revista de Serviço Público. Brasília, ano 54, n² 2, Abr./ Jun., 2003.

TEIXEIRA, Hélio Janny; SANTANA, Solange Maria. Remodelando a Gestão Pública. São Paulo: Edgard Blücher, 1995.

Note: A version in Portuguese may appear at the journal Website.

Revista Galega de Economia / Economic Review of Galicia: http:/ / www.usc.es/ econo/ RGE/ benvidag.htm 